\title{
TWO MODELS FOR ESTIMATING GLIMATE-GLAGIER RELATIONSHIPS IN THE NORTH CASGADES, WASHINGTON, U.S.A.
}

\author{
By Wendell Tangborn* \\ (U.S. Geological Survey, Tacoma, Washington 98402, U.S.A.)
}

\begin{abstract}
Two models based on standard observations of precipitation, temperature, and run-off at low-altitude weather and gaging stations have been devised to calculate annual glacier balances in the North Cascades of Washington. The predicted glacier balances of the Thunder Creek basin glaciers, determined by a run-off-precipitation (RP) model during the $1920-74$ period, are compared with balances predicted by a precipitation-temperature (PT) model for the same period. Annual balances determined by the PT model are also compared with balances measured by field techniques at South Cascade Glacier since 1958 . In the PT model, winter snow accumulation (winter balance) is determined by winter (October-April) precipitation observed at the Snoqualmie Falls weather station. Summer (May-September) ablation (summer balance) on the glaciers is estimated by a technique which utilizes maximum and minimum air temperatures, also observed at Snoqualmie Falls. Ablation calculations incorporate summer cloud cover as a variable by using a relationship between cloud cover and the range in daily maximum and minimum air temperatures.
\end{abstract}

Annual mass changes for the 1884-1974 period in both South Cascade Glacier and the Thunder Creek glaciers were reconstructed by utilizing the PT model. The fluctuations in glacier mass during this period generally agree with historical observations and show that a definite change in glacier activity from marked recession to stability or an advancing state occurred about 1945. During the 1900-45 period, South Cascade Glacier lost mass at a rate of $1.4 \mathrm{~m}$ per year and the Thunder Creek glaciers (which are at a higher altitude) at $1.1 \mathrm{~m}$ per year.

These models suggest that the relationship of glacier mass balance to precipitation and temperature is a very sensitive one. It appears from these studies that a decrease in summer air temperature of just over 0.5 $\mathrm{deg}$ or an increase in winter accumulation of slightly more than $10 \%(350 \mathrm{~mm})$ from the $1920-74$ average would cause these glaciers to grow continuously.

RÉsumé. Deux modeles pour estimer les relations climat-glacier dans les North Cascades, Washington, U.S.A. Deux modèles basés sur des observations classiques de précipitation, de température et de débit des stations météorologiques et de jaugeage de basse altitude ont été imaginés pour calculer les bilans annuels des glaciers dans les North Cascades de Washington. Les bilans prévus des glaciers du bassin de Thunder Creek, déterminés par un modèle débit-précipitation (RP) pendant la période 1920-74 sont comparés avec les bilans prévus par un modèle précipitation-température (PT) pour la même période. Les bilans annuels déterminés par le modèle PT sont aussi comparés aux bilans mesurés sur le terrain au South Cascade Glacier depuis r 958. Dans le modèle PT, l'accumulation hivernale de neige (bilan hivernal) est déterminée par les précipitations hivernales (octobre-avril) observées à la station météorologique de Snoqualmie Falls. L'ablation estivale (mai-septembre) ou bilan estival sur les glaciers est estimée par une technique qui utilise les températures minimum et maximum journalières de l'air.

La variation annuelle de masse pour la période $1884^{-1974}$ dans le South Cascade Glacier et les glaciers du Thunder Creek a été reconstituée à partir du modèle PT. Les fluctuations de la masse glaciaire durant cette période concordent généralement bien avec les observations historiques et montrent qu'une modification nette de l'activité des glaciers d'une récession sensible à un stade de stabilité ou d'avancée a eu lieu vers I 945. Durant la période $1900-45$, le South Cascade Glacier a perdu sa substance au rythme de $\mathrm{I}, 4 \mathrm{~m}$ par an et les glaciers de Thunder Creek (dont l'altitude est supérieure) à celui de $\mathrm{I}, \mathrm{I} \mathrm{m}$ par an.

Ces modèles mettent en évidence le rapport très sensible des bilans glaciaires avec les précipitations et la température. Il ressort de ces études qu'un abaissement de 0,5 deg de la température de l'air ou un accroissement dans l'accumulation hivernale d'à peine plus de $10 \%(350 \mathrm{~mm})$ sur la moyenne $1920-74$ provoquerait la croissance continue de ces glaciers.

Zusammenfassung. Zwei Modelle zur Abschätzung des Zusammenhangs zwischen Klima und Gletscher in der North Cascade Range, Washington, U.S.A. Zur Berechnung der jährlichen Gletscherbilanz in der North Cascade Range von Washington wurden zwei Modelle entworfen, die sich auf Standard-Beobachtungen des Niederschlags, der Temperatur und des Abflusses auf niedrig gelegenen Wetter- und Pegelstationen stützen. Die Vorhersage der Bilanz für die Gletscher des Thunder Creek Basin, abgeleitet aus einem Modell für Abfluss und Niederschlag der Periode $1920-74$, wird mit Bilanzen verglichen, die aus einem Modell für Niederschlag und Temperatur für dieselbe Periode vorhergesagt wurden. Jährliche Bilanzen der zweiten Art werden auch mit Bilanzen verglichen, die am South Cascade Glacier seit 1958 mit Feldmethoden gemessen wurden. Im zweiten Modell wird die Schneeakkumulation im Winter (Winterbilanz) aus dem

* Present address: URS Company, Fourth and Vine Building, Seattle, Washington 9812i, U.S.A. 
Winter- (Oktober-April)-Niederschlag bestimmt, der an der Wetterstation Snoqualmie Falls gemessen wurde. Die Ablation im Sommer (Mai-September) auf den Gletschern (Sommerbilanz) wird mit Hilfe einer Methode abgeschätzt, die maximale und minimale Lufttemperaturen, ebenfalls in Snoqualmie Falls gemessen, heranzieht. Die Ablationsrechnungen berücksichtigen die Wolkendecke im Sommer unter Anwendung einer Beziehung zwischen der Wolkendecke und der täglichen Schwankung der Lufttemperatur.

Das erste Modell wurde zur Ermittlung der jährlichen Massenänderung von 1884 bis 1974 sowohl am South Cascade Glacier wie für die Thunder Creek Gletschern herangezogen. Die Schwankungen der Eismassen während dieser Periode stimmen im allgemeinen mit historischen Beobachtungen überein und zeigen, dass ein ausgesprochener Wechsel im Gletscherverhalten von deutlichem Rückgang zu Stabilität oder gar Vorstoss um 1945 eintrat. In der Periode von 1900 bis 1945 verlor der South Cascade Glacier Masse mit einer Rate von I, $4 \mathrm{~m}$ pro Jahr, die Thunder Creek Gletschern, die in grösserer Höhe liegen, I, I m pro Jahr.

Diese Modelle lassen annehmen, dass die Beziehung zwischen der Massenbilanz von Gletschern und dem Niederschlag bzw. der Temperatur sehr empfindlich ist. Die Untersuchungen deuten darauf hin, dass eine Abnahme der sommerlichen Luftemperatur um etwas über 0,5 deg oder eine Zunahme der winterlichen Akkumulation von etwas mehr als $10 \%(350 \mathrm{~mm})$ gegenüber dem Mittel von 1920-74 ein kontinuierliches Anwachsen dieser Gletscher zur Folge hätten.

\section{INTRODUGTION}

The link between the change in a glacier's mass (the annual balance) and the local climate is relevant to reconstructing recent climatic history. The enduring chronology left by glaciers in the form of moraines, till, buried vegetation, and other ice-formed evidence is much longer and more reliable in many ways than man's weather records; thus a climate-glacier model which will explain the behavior of glaciers in terms of meteorological variables conceivably could extend the climatic record back thousands of years. Consequently it may be possible, on the basis of a reconstructed climate record, to determine whether periodicities in climate exist. If patterns in past climates emerge, it may be possible to predict the climate on which the future well being of mankind is so delicately balanced. Because a glacier has unusual sensitivity to minute climatic perturbations it may strongly amplify these subtle changes, leaving a lasting geomorphic trace.

The existence and importance of past widespread glaciation were first recognized by Agassiz (1840) and the direct connection of glaciers and climate was refined by Matthes (1942) and Ahlmann (1948, r953). Later work by Nye (1960, I963), Meier (1965), and Hoinkes (1968) demonstrates that a definite relationship exists between climate, energy exchange, mass balance, and the dynamic response of a glacier, and that the connecting links between these factors may explain the current behavior of glaciers in response to the climate of the present and recent past. The main problems in identifying these relationships are in determining how a glacier changes its mass due to measurable meteorological parameters, namely those producing winter snow accumulation and summer ablation of snow and ice, and in determining the mechanisms that relate a glacier's change in mass to fluctuations of its extent-most prominently at its terminus.

Documenting these fluctuations and relating them to climate changes requires a long record of annual balance for many glaciers of various sizes, area-altitude distributions, and orientations, all within a single climatic region. In order to encompass many climate conditions and to have a sufficient statistical sample, at least 50 years of mass-balance measurements would seem to be necessary. Unfortunately, such a collection of data is not available. However, the North Cascades area of Washington offers an opportunity for supplying the information necessary to reconstruct long-term mass-balance records for the following reasons:

I. The North Cascades area is highly glacierized, with some drainages containing scores of glaciers of various sizes and orientations (Post and others, I97 I).

2. Accurate records of stream flow have been collected from both glacier and non-glacier basins for over 50 years.

3. Records of precipitation and temperature are available from weather stations within this region for nearly roo years. 
4. Well-documented records of glacier distributions and fluctuations are available (Hubley, I956; LaChapelle, I96o; Meier and Post, I962; Meier, I964; Miller, I967; Post and others, I97I).

5. Detailed measurements of mass balance, run-off, accumulation, ablation, precipitation, temperature, and other glaciologic and meteorologic variables have been made continuously at one glacier (South Cascade) since r 958.

Two independent methods which relate long-term glacier balance with measured climatic variables are presented in this study. One is based on a run-off-precipitation (RP) model that determines annual balances in a large glacierized area in a North Cascades drainage basin (Thunder Creek), mainly by differences in run-off between this glacierized basin and a nearby, non-glacierized basin (South Fork Skykomish River). A linear relationship is then formed between the annual balance determined by the RP model and observed winter precipitation and summer temperatures at a low-altitude, long-established weather station by a precipitation-temperature (PT) model. These two models are not entirely independent because winter precipitation in the PT is related to annual precipitation in the RP model. This does not seriously affect the conclusions, chiefly because precipitation in the RP model is a minor component.

The second method is based on relating actual mass-balance measurements at South Cascade Glacier directly with precipitation and temperature observed at the same lowaltitude weather station (the PT model).

A slight inaccuracy is introduced with these methods because glaciers change in size with time. Even when climatic conditions are identical, the mass balance of a glacier which is overextended tends to be more negative than the balance of a smaller, receded glacier. Also, the change in elevation of a glacier with time tends to produce a different mass balance with the same climate, so that the balance of an expanding glacier tends to be more positive and that of a shrinking glacier more negative, each year. This effect is termed the Bodvarsson instability (Bodvarsson, 1955). These relatively small changes in both extent and altitude are neglected in this preliminary model. The intent of this study is to examine only changes of glacier mass with time and not to attempt determination of the response to this mass variation. It is hoped that the mass-balance data provided here will also be useful to those interested in dynamic modeling.

\section{Run-OFF-PREgipitation (RP) MODEL}

Two large drainages with long-term records of stream flow in the North Cascades are particularly well suited to an analysis of past glacier behavior. Thunder Creek is in a glacierized basin containing $5 \mathrm{I}$ glaciers that form a glacier cover of approximately $14.5 \%$ of the total area $\left(38.6 \mathrm{~km}^{2}\right)$. The South Fork Skykomish River is in a non-glacierized basin lying $75 \mathrm{~km}$ to the south (Figs I and 2). A preliminary version of a method to determine annual balances using these drainage basins has been described (Tangborn, 1968).

The two mountain drainage basins used in this study are similar in most respects except that, chiefly because of differences in the distribution of area with altitude, one is glacierized and the other is not. If glacier cover were the only dissimilarity, differences in annual run-off would be attributed entirely to the loss or gain in mass of the glaciers in the Thunder Creek basin. However, apparent precipitation differences between the two basins make the following development necessary.

The hydrologic balance of each basin is:

and

$$
\Delta S_{\mathrm{g}}=P_{\mathrm{g}}-R_{\mathrm{g}}-E_{\mathrm{g}} \quad \text { (Thunder Creek basin) }
$$

$$
\Delta S_{\mathrm{n}}=P_{\mathrm{n}}-R_{\mathrm{n}}-E_{\mathrm{n}} \quad \text { (South Fork Skykomish River basin), }
$$


where $\Delta S$ is the change in water storage (all forms), $P$ the precipitation, $R$ the run-off, and $E$ the net evaporation-condensation; the suffices $g$ and $\mathrm{n}$ refer to the glacierized and nonglacierized basins respectively.

The difference between $\Delta S_{\mathrm{g}}$ and $\Delta S_{\mathrm{n}}$ for any time period is the difference in the water balance for the two basins. When the variables are summed over one hydrologic year:

$$
\begin{aligned}
& S_{\mathrm{g}}=\sum_{\text {I October }}^{30 \text { September }}\left(P_{\mathrm{g}}-R_{\mathrm{g}}-E_{\mathrm{g}}\right), \\
& S_{\mathrm{n}}=\sum_{\mathrm{r} \text { October }}^{\text {September }^{2}}\left(P_{\mathrm{n}}-R_{\mathrm{n}}-E_{\mathrm{n}}\right),
\end{aligned}
$$

where $S_{\mathrm{g}}$ and $S_{\mathrm{n}}$ are annual balances for the two basins, respectively.

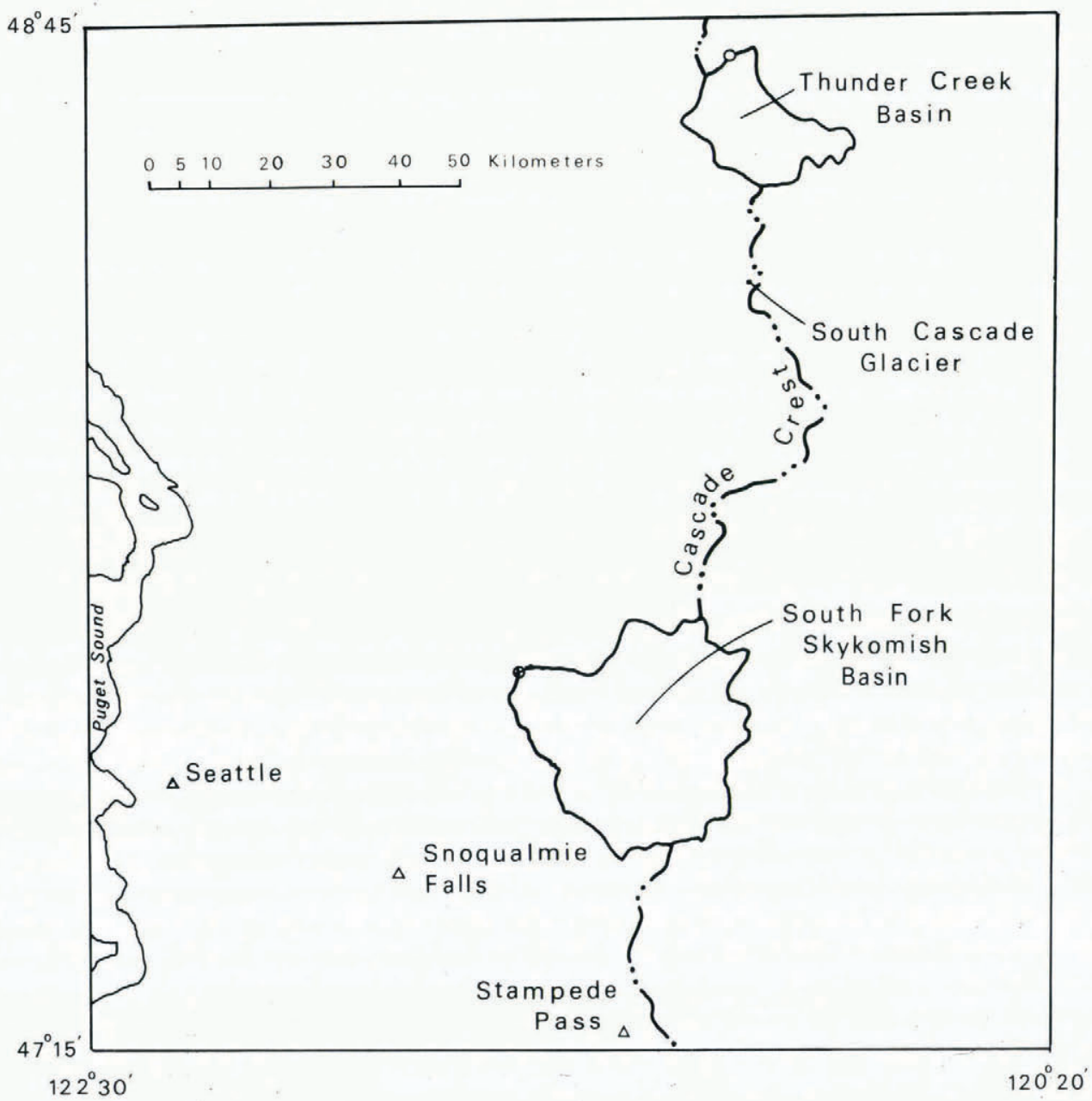

Fig. I. Location of South Cascade Glacier, the drainage basins, and the weather stations in the North Cascades that were used in the development of the climate-glacier model. 


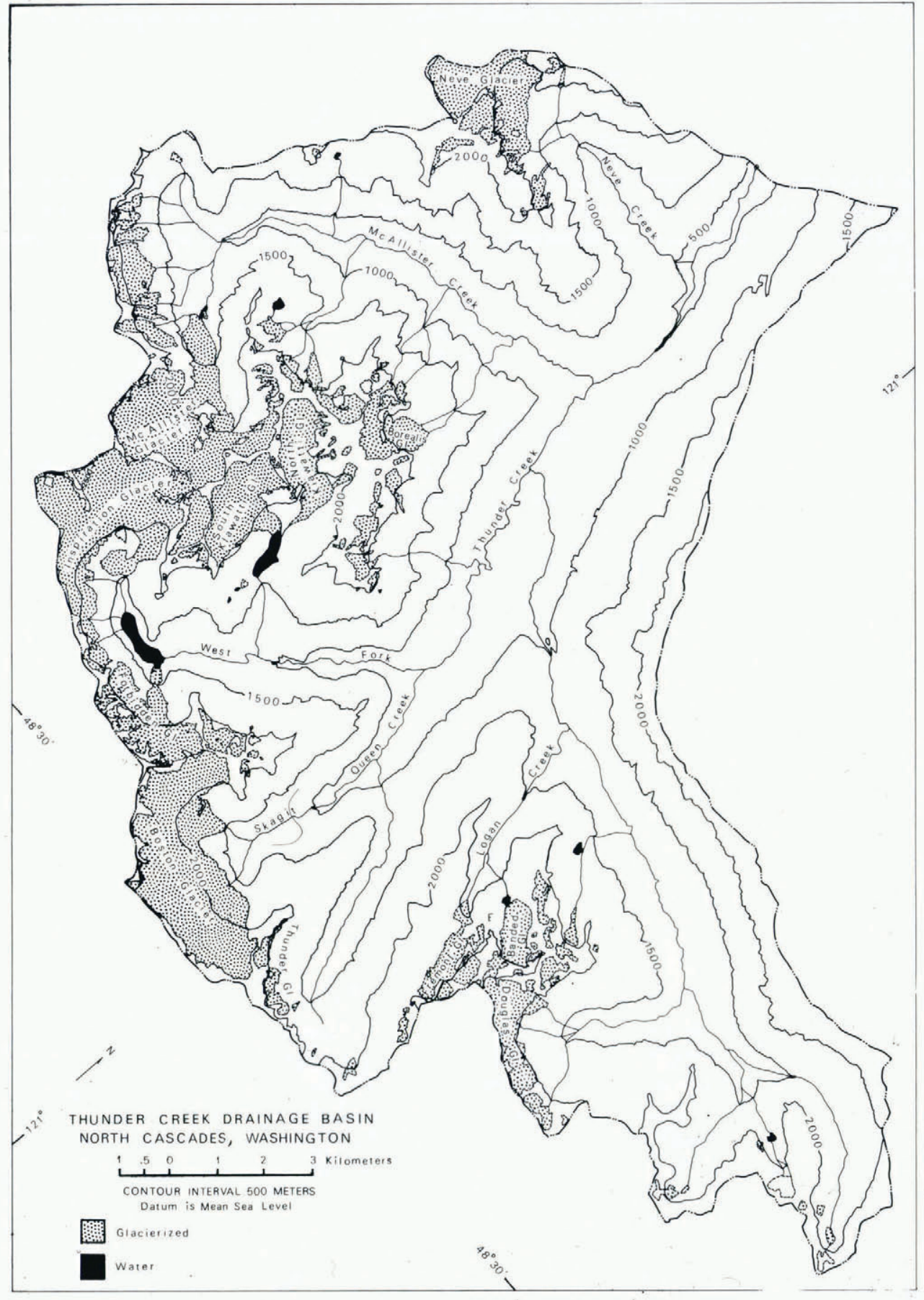

Fig. 2. The Thunder Creek basin. This drainage is $272 \mathrm{~km}^{2}$ in area, has a mean altitude of $\mathrm{I} 55^{8} \mathrm{~m}$, and contains $5 \mathrm{I}$ glaciers with a total area of $39.4 \mathrm{~km}^{2}(14.5 \%$ of the total drainage area). The mean altitude of the glacierized area is $2120 \mathrm{~m}$. Glacier boundaries are those of 1970 , interpreted from aerial photographs by Austin Post. 
The annual balance of the non-glacierized basin $\left(S_{\mathrm{n}}\right)$ is approximately equal to zero; the difference between basin balances $\left(S_{\mathrm{g}}-S_{\mathrm{n}}\right)$ is then:

$$
S_{\mathrm{g}}=\sum_{\mathrm{I} \text { October }}^{\text {3o September }}\left(R_{\mathrm{n}}-R_{\mathrm{g}}\right)-\left(P_{\mathrm{n}}-P_{\mathrm{g}}\right)-\left(E_{\mathrm{g}}-E_{\mathrm{n}}\right) .
$$

By assuming that the precipitation each basin receives is related to a single independent measurement of precipitation multiplied by a coefficient unique to that basin and by assuming that annual net evaporation-condensation is equal in these two basins, Equation (5) can be simplified.

Then

$$
\begin{aligned}
& P_{\mathrm{g}}=M p_{\mathrm{a}}, \\
& P_{\mathrm{n}}=\mathcal{N} p_{\mathrm{a}},
\end{aligned}
$$

and

$$
E_{\mathrm{g}}-E_{\mathrm{n}}=\mathrm{o},
$$

where $p_{\mathrm{a}}$ is annual precipitation measured at a valley station and $M$ and $\mathcal{N}$ are coefficients representative of the two basins, respectively. Equation (5) now becomes:

$$
S_{\mathrm{g}}=\sum_{\mathrm{r}}^{\text {3o Septober }}\left(R_{\mathrm{n}}-R_{\mathrm{g}}\right)-(M-\mathcal{N}) p_{\mathrm{a}} .
$$

The glacierized area of the Thunder Creek basin (currently $14.5 \%$ of the total area) is the chief source of annual water-balance variations, so $S_{\mathrm{g}}$ divided by this fraction of the total basin area is equal to the annual balance, $B_{\mathrm{a}}{ }^{\star \star}$, and average of all the glaciers in the basin:

$$
B_{\mathrm{a}}^{\star \star}=S_{\mathrm{g}} / A_{\mathrm{f}}
$$

where $A_{\mathrm{f}}$ is the fraction of glacier cover.

The final expression can be simplified to

$$
B_{\mathrm{a}}{ }^{\star \star}=\frac{\mathrm{I}}{A_{\mathrm{f}}}\left(\left(R_{\mathrm{n}}-R_{\mathrm{g}}\right)-k p_{\mathrm{a}}\right),
$$

where $B_{\mathrm{a}}, R_{\mathrm{n}}, R_{\mathrm{g}}$, and $p_{\mathrm{a}}$ are all hydrologic year (1 October-3o September) values.

A value for the coefficient $k$ can be found if $B_{\mathrm{a}}$ is known for a period of time greater than one year:

$$
k=\left(R_{\mathrm{n}}-R_{\mathrm{g}}-A_{\mathrm{f}} B_{\mathrm{a}} \star \star\right) / p_{\mathrm{a}} .
$$

The period used for the calculation of $k$ was $1947-6$ I because two of the larger glaciers (North and South Klawatti Glaciers) in this basin were mapped in September of 1947 and I96I (Meier, I966). The mass changes determined for these glaciers during this i4 year period (one gained $5.8 \mathrm{~m}$ of ice, the other lost $8.3 \mathrm{~m}$ ) and the area-altitude distribution for each glacier has been used to calculate a distribution of balance with altitude that was consistent for both glaciers and a paper describing this work is in preparation by W. V. Tangborn, W. G. Sikonia, and M. F. Meier. Thus the large difference in mass change of the Klawatti Glaciers appears to be caused entirely by the difference in area-altitude distributions. The application of this same balance-altitude function to the area-altitude distribution of the combined glaciers in Thunder Creek basin showed a total mass change of $-0.3 \mathrm{~m}$ for these glaciers during the I947-6r period. A value of 0.305 for $k$ was determined using Equation (8).

The average value of $A_{\mathrm{f}}$ during the 1947-6I period was 0.145 (Post and others, I97 I). As the final snow cover at the end of each ablation season is indistinguishable hydrologically from the glacier cover, $A_{\mathrm{f}}$ is somewhat dependent on $B_{\mathrm{a}}$ (if $B_{\mathrm{a}}$ is very positive, $A_{\mathrm{f}}$ will be 
greater than its average value). However, the error this produces is small because the quantity remaining is usually insignificant relative to glacier ice, and $A_{\mathrm{f}}$ is assumed to be reasonably constant during the entire $1920-74$ period.

The predicted annual balance for the Thunder Creek glaciers is then determined by:

$$
B_{\mathrm{a}}{ }^{\star \star}=6.90\left(R_{\mathrm{n}}-R_{\mathrm{g}}\right)-2 . \operatorname{Ior} p_{\mathrm{a}} \text {. }
$$

Results for the $1920-74$ period (for which run-off and precipitation data are available) are shown in Figure 3 (cumulative balance), and in Table I (column $B_{\mathrm{a}} \star \star(2)$ ).

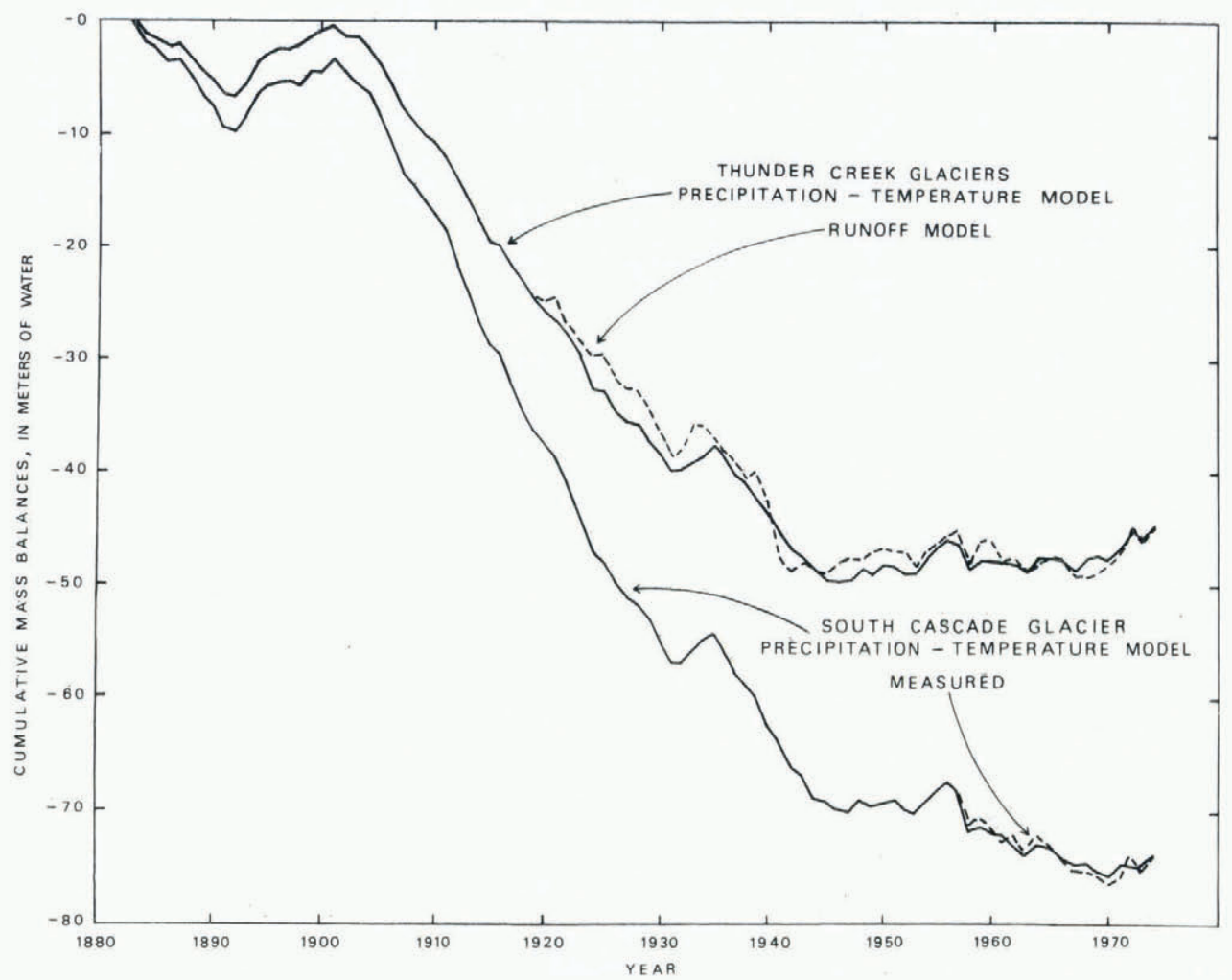

Fig. 3. Cumulative balances for the Thunder Creek glaciers (upper curves) and South Cascade Glacier (lower curves) for the $1884^{-1974}$ period. The solid lines are cumulative annual balances derived from the precipitation-temperature model. The dashed curve for the Thunder Creek glaciers is from balances calculated by the run-off model. (1920-74). The dashed curve for South Cascade Glacier is from actual field measurements of annual balance (1958-74).

\section{Precipitation-temperature (PT) model, Thunder Creek glaciers}

Precipitation and temperature have been measured and recorded by standard methods at a few sites throughout the world since the beginning of the eighteenth century (Manley, I948; Brooks, 1949). A glacier-balance model that incorporated only these easily measured variables would be useful for interpreting both past and current glacier behavior in relation to climate. In a study similar to this one, mass balances for Lednik IGAN in the Polar Urals have been estimated for the $1818-1962$ period by calculations using meteorological data from the Syktyvkav weather station (Troitskiy and others, 1966).

The weather station used in the North Cascades study, Snoqualmie Falls (Fig. I), lies $125 \mathrm{~km}$ south-west of the Thunder Creek basin and I Io km south-west of South Cascade 
Table I. Annual balances of the Thunder Creek glaciers and annual, winter, and summer balances of South Cascade Glacier determined by the PT and RP models and by Field measurements

(Note: Values are in meters of water equivalent)

$\begin{array}{lrrrr}r \text { ear } & B_{\mathrm{a}}{ }^{\star}(\mathrm{r}) & B_{\mathrm{a}}{ }^{*}(3) & B_{\mathrm{w}} & B_{\mathrm{s}} \\ 1884 & -1.1 & -1.4 & 3.0 & 4.4 \\ 1885 & -0.6 & -1.0 & 3.2 & 4.2 \\ 1886 & -0.5 & -0.9 & 3.4 & 4.3 \\ 1887 & 0.1 & 0.0 & 3.4 & 3.4 \\ 1888-1.1 & -1.7 & 3.2 & 4.9 \\ 1889 & -1.2 & -1.5 & 2.7 & 4.2 \\ 1890 & -0.7 & -0.9 & 2.9 & 3.8 \\ 1891 & -1.3 & -1.6 & 2.7 & 4.4 \\ 1892 & -0.5 & -0.7 & 3.0 & 3.8 \\ 1893 & 1.5 & 1.7 & 3.8 & 2.1 \\ 1894 & 1.6 & 1.5 & 4.2 & 2.7 \\ 1895 & 0.8 & 0.9 & 3.4 & 2.5 \\ 1896 & 0.4 & -1.4 & 3.2 & 2.8 \\ 1897 & 0.4 & 0.2 & 3.6 & 2.4 \\ 1898 & 0.1 & -0.2 & 3.8 & 3.9 \\ 1899 & 0.1 & -0.8 & 3.5 & 2.7 \\ 1900 & 0.2 & 0.0 & 3.3 & 3.3 \\ 1901 & 0.6 & 1.2 & 3.7 & 2.4 \\ 1902 & -0.7 & -1.0 & 3.1 & 4.1 \\ 1903 & -0.5 & -0.8 & 3.8 & 4.7 \\ 1904 & -0.8 & -1.0 & 3.8 & 4.7 \\ 1905 & -1.6 & -2.2 & 2.9 & 5.0 \\ 1906 & -2.0 & -2.6 & 2.5 & 5.1 \\ 1907 & -1.7 & -2.2 & 2.8 & 4.9 \\ 1908 & -1.2 & -1.5 & 2.8 & 4.3 \\ 1909 & -1.2 & -1.4 & 2.8 & 4.2 \\ 1910 & -0.7 & -1.1 & 3.7 & 4.8 \\ 1911 & -1.2 & -1.6 & 2.7 & 4.3 \\ 1912 & -2.0 & -2.6 & 2.4 & 5.0 \\ 1913 & -1.6 & -2.2 & 2.9 & 5.1 \\ 1914 & -1.8 & -2.4 & 2.8 & 5.1 \\ 1915 & -2.1 & -2.9 & 2.4 & 5.2 \\ 1916 & -0.4 & -0.8 & 3.6 & 4.5 \\ 1917 & -1.7 & -2.4 & 2.8 & 5.1 \\ 1918 & -1.4 & -2.3 & 3.5 & 5.8 \\ 1919 & -1.3 & -1.9 & 3.6 & 5.5 \\ & & & & \end{array}$

$\begin{array}{lrrrrr}\text { Year } & B_{\mathrm{a}^{\star}}(\mathrm{I}) & B_{\mathrm{a}}{ }^{\star}(2) & B_{\mathrm{a}}{ }^{\star}(3) & B_{\mathrm{w}}{ }^{\star} & B_{\mathrm{s}}{ }^{*} \\ 1920 & -1.1 & -0.5 & -1.6 & 2.8 & 4.4 \\ 1921 & -0.9 & 0.6 & -1.4 & 3.1 & 4.5 \\ 1922 & -1.7 & -2.8 & -2.4 & 2.9 & 5.3 \\ 1923 & -1.8 & -1.2 & -2.6 & 2.9 & 5.5 \\ 1924 & -2.4 & -1.4 & -3.3 & 2.8 & 6.0 \\ 1925 & -0.5 & 0.2 & -0.8 & 3.1 & 4.0 \\ 1926 & -1.9 & -2.2 & -2.3 & 2.4 & 4.6 \\ 1927 & -0.5 & -1.0 & -0.9 & 3.1 & 4.0 \\ 1928 & -0.5 & -0.1 & -0.9 & 3.4 & 4.2 \\ 1929 & -1.4 & -1.9 & -1.6 & 2.5 & 4.0 \\ 1930 & -1.2 & -1.6 & -1.4 & 2.4 & 3.8 \\ 1931 & -1.6 & -2.1 & -1.9 & 2.6 & 4.6 \\ 1932 & 0.1 & 0.3 & 0.0 & 3.6 & 3.7 \\ 1933 & 0.8 & 2.4 & 0.9 & 3.9 & 3.0 \\ 1934 & 0.8 & -0.3 & 0.7 & 4.3 & 3.6 \\ 1935 & 0.5 & -0.7 & 0.6 & 3.6 & 3.0 \\ 1936 & -1.3 & -1.3 & -1.6 & 2.7 & 4.4 \\ 1937 & -1.1 & -1.0 & -1.5 & 2.7 & 4.2 \\ 1938 & -1.0 & -1.7 & -1.2 & 3.4 & 4.6 \\ 1939 & -1.3 & 0.6 & -1.4 & 2.5 & 3.9 \\ 1940 & -1.4 & -2.4 & -1.8 & 3.2 & 4.9 \\ 1941 & -1.4 & -4.8 & -1.8 & 2.2 & 4.0 \\ 1942 & -1.4 & -1.2 & -2.1 & 2.7 & 4.7 \\ 1943 & -0.6 & 0.6 & -0.8 & 3.2 & 4.0 \\ 1944 & -1.6 & -0.7 & -2.0 & 2.3 & 4.3 \\ 1945 & -0.6 & -0.4 & -0.7 & 3.2 & 3.9 \\ 1946 & -0.3 & 0.9 & -0.7 & 3.5 & 4.2 \\ 1947 & 0.0 & 0.7 & -0.2 & 3.6 & 3.8 \\ 1948 & 1.1 & 0.0 & 0.9 & 4.2 & 3.3 \\ 1949 & -0.4 & 0.3 & -0.4 & 3.2 & 3.6 \\ 1950 & 0.9 & 0.7 & 0.9 & 4.3 & 3.4 \\ 1951 & -0.1 & -0.6 & -0.1 & 3.9 & 4.0 \\ 1952 & -0.8 & -1.1 & -1.0 & 2.8 & 3.7 \\ 1953 & 0.0 & -0.1 & -0.3 & 3.0 & 3.3 \\ 1954 & 1.6 & 1.3 & 1.5 & 3.9 & 2.3 \\ 1955 & 0.8 & 0.5 & 0.9 & 2.9 & 2.1 \\ 1956 & 0.6 & 0.9 & 0.3 & 4.2 & 3.9 \\ 1957-0.4 & 0.4 & -0.8 & 3.2 & 4.1\end{array}$

$\begin{array}{lrrrrrr}\text { Year } & B_{\mathrm{a}}(\mathrm{I}) & B_{\mathrm{a}} \star \star(2) & B_{\mathrm{a}}{ }^{*}(3) & B_{\mathrm{a}}(4) & B_{\mathrm{w}}{ }^{\star} & B_{\mathrm{a}} \star \\ 1958 & -2.3 & -2.9 & -3.3 & -3.3 & 3.1 & 6.4 \\ 1959 & 0.8 & 1.9 & 0.4 & 0.7 & 4.0 & 3.6 \\ 1960 & -0.1 & 0.0 & -0.5 & -0.5 & 3.3 & 3.8 \\ 1961 & -0.1 & -1.7 & -0.7 & -1.1 & 4.2 & 4.9 \\ 1962 & -0.1 & 0.4 & -0.4 & 0.2 & 2.9 & 3.3 \\ 1963 & -0.6 & -1.0 & -1.1 & -1.3 & 2.8 & 3.9 \\ 1964 & 1.3 & 0.6 & 1.0 & 1.2 & 3.8 & 2.8 \\ 1965 & -0.1 & 0.4 & -0.4 & 0.1 & 3.2 & 3.7 \\ 1966 & -0.5 & -0.4 & -1.0 & -0.9 & 3.0 & 4.0 \\ 1967 & -0.5 & -1.0 & -1.0 & -0.6 & 3.8 & 4.8 \\ 1968 & 0.8 & 0.0 & 0.4 & 0.0 & 3.8 & 3.4 \\ 1969 & 0.0 & 0.0 & -0.5 & -0.6 & 3.4 & 3.9 \\ 1970 & -0.1 & -0.1 & -0.4 & -1.1 & 3.1 & 3.4 \\ 1971 & 1.2 & 1.0 & 0.9 & 0.6 & 4.1 & 3.2 \\ 1972 & 1.4 & 2.1 & 1.0 & 1.4 & 4.5 & 3.6 \\ 1973 & -0.8 & -1.0 & -1.0 & -1.0 & 2.3 & 3.3 \\ 1974 & 1.4 & 1.7 & 1.2 & 1.0 & 4.6 & 3.5\end{array}$

List of symbols:

$$
\begin{aligned}
& B_{\mathrm{a}} \star(1)=\text { Thunder Creek glaciers, annual balance, PT model, r884-1974. } \\
& B_{\mathrm{a}} \star \star \\
& B_{\mathrm{a}}{ }^{*}=\text { Thunder Creek glaciers, annual balance, RP model, } 1920-74 . \\
&=\text { South Cascade Glacier, annual balance, PT model, } 1884-1974 . \\
& B_{\mathrm{a}}(4)=\text { South Cascade Glacier, annual balance, measured, } 1958-74 . \\
& B_{\mathrm{w}}=\text { South Cascade Glacier, winter balance, PT model, } 1884-1974 . \\
& B_{\mathrm{s}} \star=\text { South Cascade Glacier, summer balance, PT model, 1884-1974. }
\end{aligned}
$$

Glacier. Even though it is located some distance from these glaciers and at a much lower altitude (13 I m), its unbroken record (1899-1974) and apparent good correlation with currently operated high-altitude and other lowland stations made it the only logical choice in this region. It was necessary to use two other lowland stations, Seattle and North Head (on the Pacific Coast) to extrapolate precipitation and temperature data for the period prior to I899. The precipitation record was extended to 1884 by a linear regression of monthly values at this station to that observed at Seattle-a station which has been in continuous operation since I 884. The correlation between Snoqualmie Falls and Seattle is high for most winter months during the $1884-98$ period, and the extrapolation of precipitation data to 1884 is considered quite accurate.

Extending the temperature record at Snoqualmie Falls was more difficult. The stations and period used are North Head (1884-1930) and Seattle (1893-1974). The procedure was first to extend the Seattle maximum and minimum monthly temperature records to 1884 by the parallel North Head-Seattle period of 1893-1930. Mean lapse-rates between the two stations were then used for each month to construct the missing Seattle record. The parallel 1899-1974 Seattle-Snoqualmie Falls period was then used to extend the Snoqualmie Falls record to $\mathrm{i} 884$. In this way the maximum length of simultaneous temperature records was used for each of the three stations. The final result is a synthetic temperature record for Snoqualmie Falls, from I 884 to I898, constructed from both North Head and Seattle data. 
The reliability of the data for this early period naturally is considered less than that observed during the 1899-1974 period.

The annual balance $B_{\mathrm{a}}$ of a glacier is the end result of two large mass changes: $B_{\mathrm{w}}$, winter accumulation of snow, and $B_{\mathrm{s}}$, summer ablation of both ice and snow. In the North Cascades, balance is usually an order of magnitude less than either accumulation and ablation. High accuracy is therefore often difficult to obtain, even with detailed field measurements (Meier and Tangborn, 1965; Meier and others, 1971).

Total annual accumulation and ablation are not measured by these two models and current mass-balance terminology cannot be applied. The balance symbols used in the PT and RP models are similar in concept to those in standard terminology (UNESCO/IASH, I970; Mayo and others, I972). However, there are significant differences in the techniques used for obtaining balance values with the PT and RP models and those obtained by the usual field measurements. New symbols are necessary and the relationship between these and standard balance terminology are shown in Table II.

TABLE II. RELATION BETWEEN SYMBOLS USED IN THIS PAPER AND STANDARD BALANCE TERMINOLOGY

Term

Winter balance on 30 April

Summer balance for the I May to 30 September season

Annual balance on 30 September

$$
\text { RP model } \quad P T \text { model }
$$
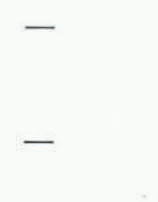

$$
B_{\mathrm{w}} \star
$$$$
B_{\mathrm{a}} \star \star \quad B_{\mathrm{a}} \star=B_{\mathrm{w}} \star-B_{\mathrm{g}} \star \quad \int_{1 \text { October }}^{30 \text { April }} C \mathrm{~d} t-\int_{\mathrm{I} \text { May }}^{30 \text { September }} A \mathrm{~d} t
$$

The dates (30 April and 30 September) which end the winter and summer seasons were chosen for this analysis on the basis of when accumulation and ablation are dominant at South Cascade Glacier: these are also the dates used in the Kårsa Glaciären study in Sweden (Wallén, I948).

Snowfall occurring at high altitudes in the North Cascades of Washington appears to be closely related to precipitation recorded at low-altitude valley stations (Rasmussen and Tangborn, 1976; Tangborn and Rasmussen, 1976). Although winter precipitation occurs mostly as rain at low altitudes, snowfall is dominant above I $500 \mathrm{~m}$. Periods of heavy rainfall do occasionally occur during the October-April season at glacier altitudes; however, winter run-off in this region is negligible as shown by observations at the South Cascade Glacier gaging station-because of the refreezing of water within the cold snow-pack and the storage of liquid water within the glacier (Tangborn and others, [1975]).

Winter accumulation (the winter balance) on North Cascades glaciers is approximated by winter precipitation recorded at Snoqualmie Falls $\left(p_{\mathrm{w}}\right)$ :

$$
B_{\mathrm{w}}{ }^{\star}=a p_{\mathrm{w}} .
$$

From studies on South Cascade Glacier it has been found that an average of $35 \%$ of the winter accumulation on this glacier is derived by wind-drifting and avalanching of snow from the adjacent slopes (Tangborn and others, 1977). There is some indication that this additional nourishment is a function of actual snowfall, so that a winter of high precipitation produces correspondingly greater deposits of avalanched and drifted snow on the glacier surface than a winter of low precipitation. 
Ablation from snow and ice surfaces is not easily measured accurately by direct means, and is extremely difficult to model from meteorological parameters, particularly over long periods of time (LaChapelle, r 959; Hoinkes, I 955; Paterson, I 969; Hubley, I 957; Müller and Keeler, 1969). Summer snowfall has also been used as a variable in estimating ablation (Hoinkes, I968; Hoinkes and others, I968) but its use is only implicit in these models. Compared with several theoretical ablation models that have been developed, usually for a single point or small area on a glacier, the method described here is undeniably crude. Although an attempt has been made to develop a physically real system, the limitation imposed by using only measured temperature creates an unavoidably empirical means of estimating ablation. It is hoped that neglecting such important ablation factors as albedo and its changes with time, surface roughness, condensation, humidity, and wind is compensated for by the extreme simplicity of this method of estimating total ablation. Undoubtedly several of these factors are implicitly included by the use of air temperature as a variable. The fact that temperature appears to be closely related to ablation is probably caused more by the similarity of air temperature and ablation as functions of the energy processes producing ablation and air warming - namely the radiation balance-than by any direct effects.

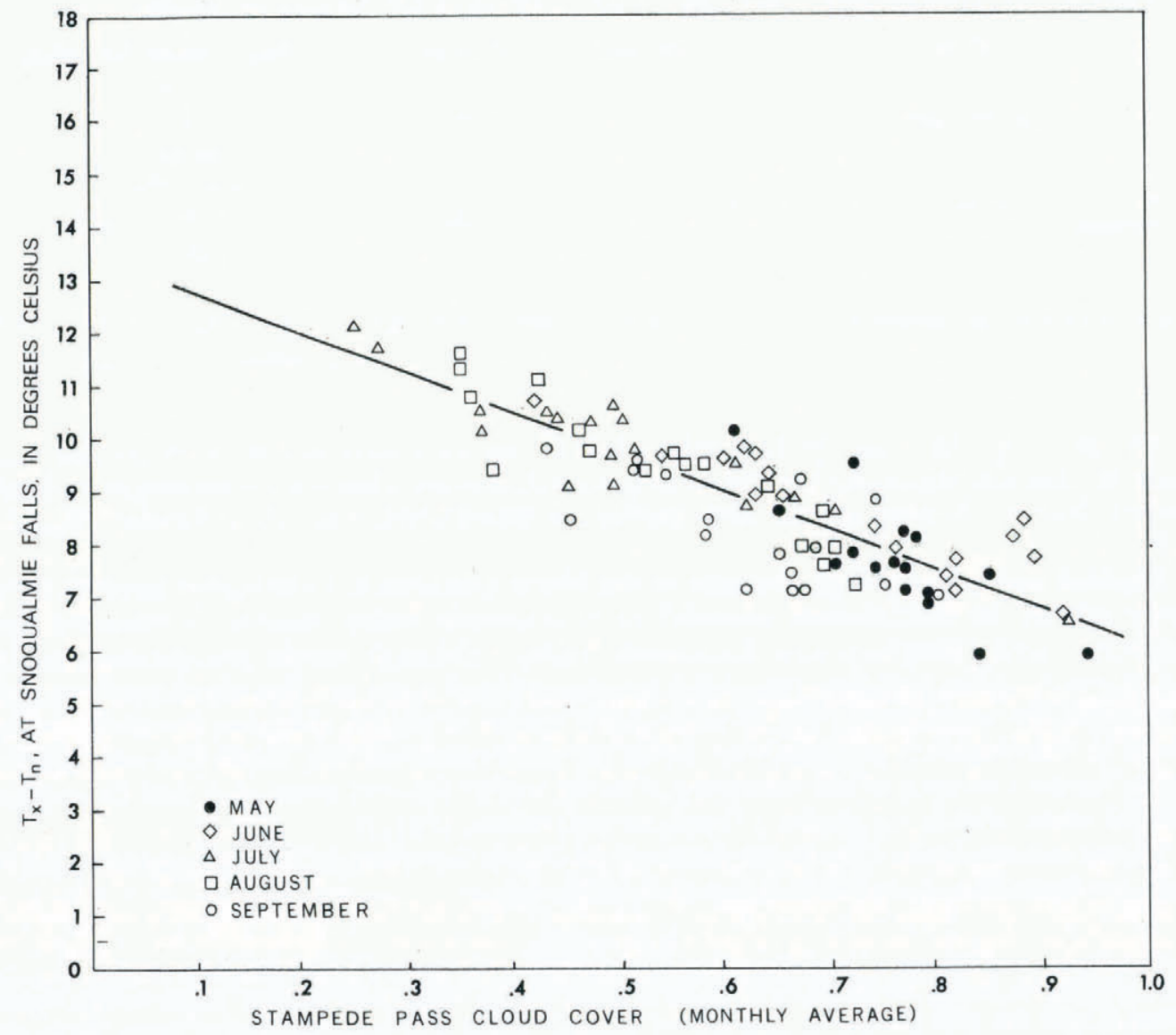

Fig. 4. The relation between monthly mean cloud cover at Stampede Pass and the range between the mean monthly maximum and minimum temperatures at Snoqualmie Falls. Cloud cover is an average based on six observations per day, and temperatures are an average of daily maximum and minimum observations. The correlation coefficient for this sample is o.87. The period used was $195^{8-73}$. 
Two main components of ablation energy were approximated in this approach: convective, which is primarily the turbulent energy exchange between the air and snow surface and the heat energy released by condensation (both are assumed to be related to mean air temperature); and radiative, which includes both incoming solar radiation and the net exchange of long-wave radiation between the snow and ice surface and the sky. Both radiation components depend on sky cover, but they are of opposite sign with regard to ablation. The part of total summer ablation caused by convective forms is designated $B_{\mathrm{h}}$, and that caused by radiative forms by $B_{\mathrm{r}}$, so that the summer balance $B_{\mathrm{s}}{ }^{\star}$ is the sum of both:

$$
B_{\mathrm{s}}{ }^{\star}=B_{\mathrm{h}}+B_{\mathrm{r}} \text {. }
$$

$B_{\mathrm{h}}$ is estimated by mean air temperature during the summer (May-September season):

$$
B_{\mathrm{h}}=C_{\mathrm{I}} \bar{T}_{\mathrm{s}}+C_{2},
$$

where $C_{1}$ and $C_{2}$ are coefficients and $\bar{T}_{\mathrm{s}}$ is equal to the average of the mean monthly temperature at Snoqualmie Falls. It should be emphasized that this relationship is not one of cause and effect; that is, air temperature by itself is not a significant force in producing ablation but is an index of other forms of energy.

$B_{\mathrm{r}}$ is approximated by a linear relation to mean cloud cover, $n$ :

$$
B_{\mathrm{r}}=D_{1} n+D_{2} \text {. }
$$

Cloud-cover observations in the North Cascades are limited to those at Stampede Pass, I $50 \mathrm{~km}$ south of the Thunder Creek basin, beginning in 1948 and continuing to the present day. The brevity of this record precludes the direct use of these data for ablation modeling over a long period of time.

A relationship between mean monthly cloud cover at Stampede Pass and the spread between the mean monthly maximum and mean monthly minimum temperatures $(\Delta T)$ at Snoqualmie Falls is shown in Figure 4. There is an obvious physical basis for such good agreement between temperature spread and cloud cover. The monthly means of maximum and minimum temperatures are derived from the average of the observed daily maxima and minima. Thus, from meteorological considerations it can be reasoned that daytime warming and night-time cooling due to cloud cover strongly affect the temperature range. Precedence for such a concept has been given in other studies (Angström, 1925; U.S. Army. Corps of Engineers, I956, p. 238; Geiger, I961). In the North Cascades a better relationship between observed cloud cover and temperature results when the mean monthly range is used instead of either the minimum or maximum. Based on this relationship, the mean cloud cover for each May-September season extending back to I 884 was estimated (Fig. 5) and used in the balance model. The higher-than-average apparent cloud cover since about 1952, which is quite striking, appears to be related to the more stable glacier balances during the $195^{2-74}$ period.

A function can now be formed that implicitly includes cloud cover and relates summer balance to maximum and minimum summer temperatures:

$$
B_{\mathrm{s}} \star=\beta \bar{T}_{\mathrm{s}}+\sigma \Delta T_{\mathrm{s}}+\delta,
$$

and the final equation relating annual glacier balance to winter precipitation and summer temperature is an equation which can be solved by multiple linear regression techniques:

$$
B_{\mathrm{a}}^{\star \star}=\alpha p_{\mathrm{w}}-\left(\beta \bar{T}_{\mathrm{s}}+\sigma \Delta T_{\mathrm{s}}+\delta\right),
$$

where $B_{\mathrm{a}}{ }^{\star \star}$ is the annual balance for the Thunder Creek glaciers calculated with the RP model, $p_{\mathrm{w}}$ is the total winter precipitation, $\bar{T}_{\mathrm{s}}$ is the mean summer temperature, and $\Delta T_{\mathrm{s}}$ the mean monthly range of daily temperatures at Snoqualmie Falls. The statistical results, when $B_{\text {a }}$ determined by the run-off model is fit with these variables, are given in Table III.

Some physical meaning is present in Equation (I4), as the values obtained by an unconstrained, least-squares fit between these variables and annual balances appear to have significance. The value determined for $\alpha$ indicates an average winter accumulation of $3.5 \mathrm{~m}$, 
which appears reasonable compared to measured values on other glaciers in this region. The values for the coefficients $\beta$ and $\sigma$ give some indication of the relative influence of the convective and radiative components. The $t$ value, another statistical means of assessing the weight of each factor, indicates that winter precipitation is the most influential, and cloud cover the least, in determining balance. The mean temperature coefficient is about three times

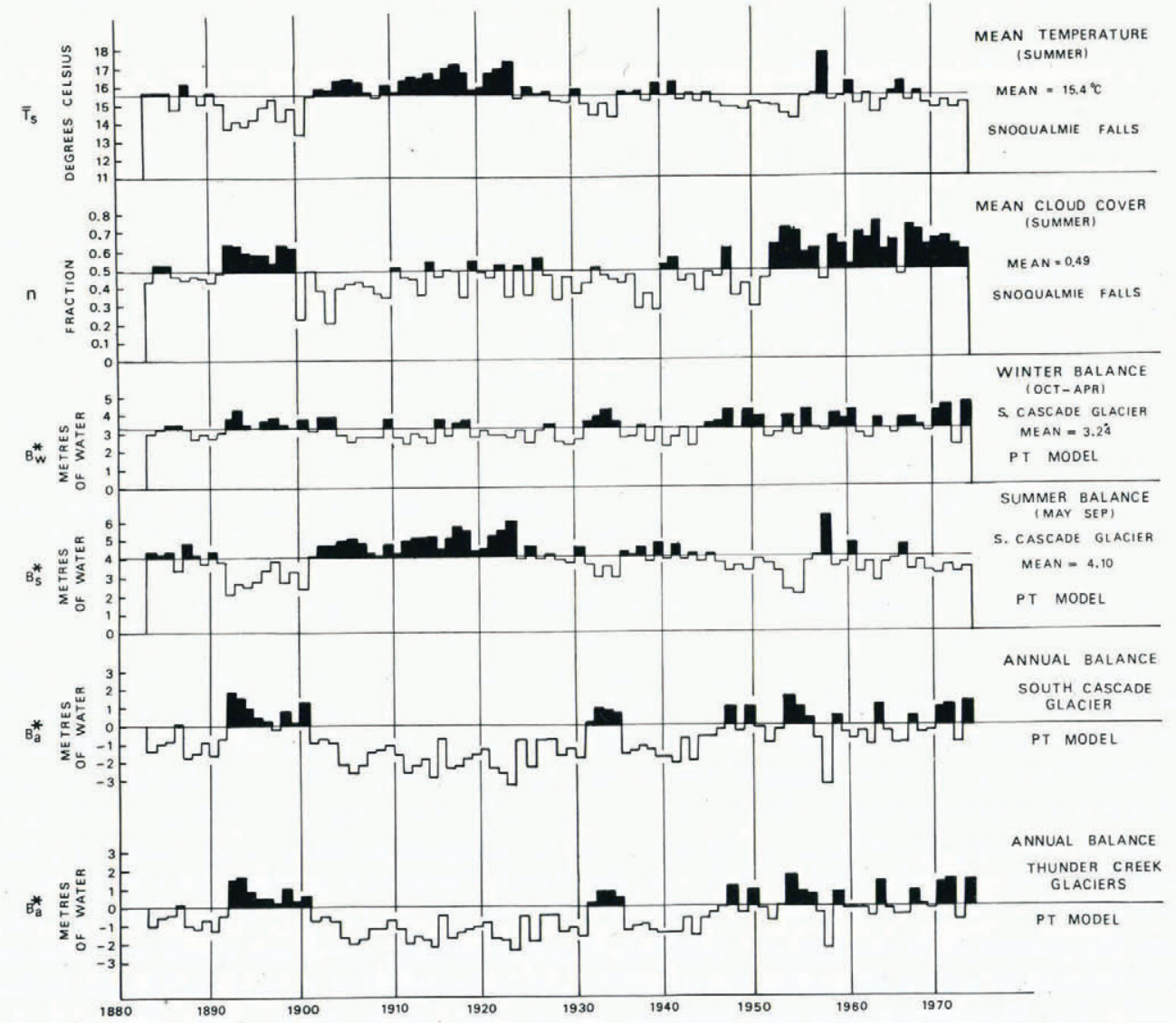

Fig. 5. Annual values of mean summer (May-September) temperature at Snoqualmie Falls $\left(\bar{T}_{\mathrm{s}}\right)$, and mean summer cloudcover fraction at Stampede Pass ( $n$ ) (based on the relationship between cloud cover at Stampede Pass and temperature at Snoqualmie Falls). Winter (October-April) balance $\left(B_{\mathrm{w}^{\star}}{ }^{*}\right)$ is for South Cascade Glacier, based on winter precipitation at Snoqualmie Falls. The summer balance is that determined by the PT model for South Cascade Glacier and the Thunder Creek glaciers. The mean value of each variable (except annual balances) is given for the period 1884-1974. Positive deviations from this mean are shaded.

TABLE III. Results of Fitting anNual balances to PREcipitation AND temperature by EQUation (14) FOR THE PERIOD 1920-74

\begin{tabular}{|c|c|c|c|c|c|c|}
\hline \multirow[b]{2}{*}{ Variable } & \multicolumn{2}{|c|}{ Coefficient } & \multirow{2}{*}{$\begin{array}{l}\text { Independent } \\
\text { correlation } \\
\text { with } B_{\mathrm{a}}\end{array}$} & \multirow[b]{2}{*}{$t$ value* } & \multirow{2}{*}{$\begin{array}{c}\text { Mean } \\
\text { value of } \\
\text { variable }\end{array}$} & \multirow{2}{*}{$\begin{array}{l}\text { Standard } \\
\text { deviation }\end{array}$} \\
\hline & Symbol & Value & & & & \\
\hline & $\alpha$ & 2.629 & 0.603 & $5 \cdot 32$ & $1.19 \mathrm{~m}$ & $0.228 \mathrm{~m}$ \\
\hline $\bar{T}_{\mathrm{s}}$ & $\beta$ & 0.59 & 0.543 & -3.93 & $15.2^{\circ} \mathrm{C}$ & $0.63 \mathrm{deg}$ \\
\hline$\Delta T_{\mathrm{s}}$ & $\delta$ & $\begin{array}{l}0.217 \\
10.85 \text { (intercept) }\end{array}$ & 0.437 & $-2.2 \mathrm{I}$ & 13.6 deg & I.24 deg \\
\hline
\end{tabular}

$* t$ value $=$ coefficient $/$ standard error of coefficient. 
that of the temperature-spread coefficient (the averages for $\bar{T}_{\mathrm{s}}$ and $\Delta T_{\mathrm{s}}$ are nearly equal, so that the relative size of each coefficient is significant). The negative sign of the radiative coefficient signifies that ablation energy from radiation sources is inversely proportional to cloud cover. This finding appears to disagree with the results of two other studies (Holmgren, I97I; Ambach, 1974) which show that long-wave radiation is a stronger factor in snow and ice ablation than is incoming short-wave isolation; thus ablation increases with cloudiness. However, both of these studies were conducted on high-altitude ice caps, and the conclusion is reached that long-wave radiation is more influential only when the albedo is greater than 0.75, which is higher than the mean summer albedo of 0.60 for these glaciers (Meier, I966). It does agree with other findings that show ablation decreasing with increasing cloudiness (Wallén, 1948; LaChapelle, 1959).

A significant amount of interdependence probably exists between $\bar{T}_{\mathrm{s}}$ and $\Delta T_{\mathrm{s}}$, and the conclusions given here may be very tenuous. In addition, temperature and precipitation tend to be inversely correlated (cool and wet or warm and dry weather often coincide), so that complete independence between accumulation and ablation calculations is not possible. As the PT and RP models are not independent, the prediction accuracy of either model by a direct comparison of $B_{\mathrm{a}}{ }^{\star}$ and $B_{\mathrm{a}}{ }^{\star \star}$ cannot be determined. The annual balances of the Thunder Creek glaciers for the $1920-74$ period (RP model) and for the I884-I974 period (PT model) are given in Table I and Figure 5 .

\section{Application to South Cascade Glacier}

An independent test of the PT model was made by applying Equation (I4) and fitting precipitation and temperature values from the same low-altitude station to annual balance measured by field techniques at South Cascade Glacier during the $195^{8-74}$ period (Table I, $\left.B_{\mathrm{a}}(4)\right)$.

The results for the multiple-regression coefficients given by Equation (14) are:

$$
B_{\mathrm{a}}{ }^{\star \star}=2.74 p_{\mathrm{w}}-0.98 \bar{T}_{\mathrm{s}}-0.13 \Delta T_{\mathrm{s}}+\mathrm{I} 2.87,
$$

with a standard error of estimate for $B_{\mathrm{a}}{ }^{\star \star}$ of $0.43 \mathrm{~m}$ (Table I, $B_{\mathrm{a}}{ }^{\star \star}(3)$, and Fig. 6).

The precipitation coefficient is slightly larger than, and the ablation coefficients are nearly equal to, those given for the Thunder Creek glaciers. The independently estimated rgro-67 winter balance for South Cascade Glacier (based partly on actual measurements), is 3.1 m (Tangborn and others, 1977); the value given by the PT model (3.2 m) is only slightly larger. The mean measured winter balance for the $1966-74$ period is $3.1 \mathrm{~m}$, while that given by this model for the same period is $3.6 \mathrm{~m}$.

The apparently greater influence of mean temperature over cloud cover on summer ablation may or may not be real. It seems reasonable that the higher-altitude Thunder Creek glaciers, located on the east side of the main Cascade Crest, may be more influenced by cloudcover variations than is South Cascade Glacier, which is less exposed to direct insolation.

\section{BALANCE History (I884-I974)}

The cumulative mass balance of both the Thunder Creek glaciers and South Cascade Glacier can now be calculated with the PT model using standard precipitation and temperature observations. Results for the past $9 \mathrm{I}$ years are shown in Figures 3 and 5 . The mass change of the Thunder Creek glaciers since r 920 given by the RP model is also shown (dashed), and the measured mass balance, cumulative since $195^{8}$, is shown (dashed) for South Cascade Glacier. 


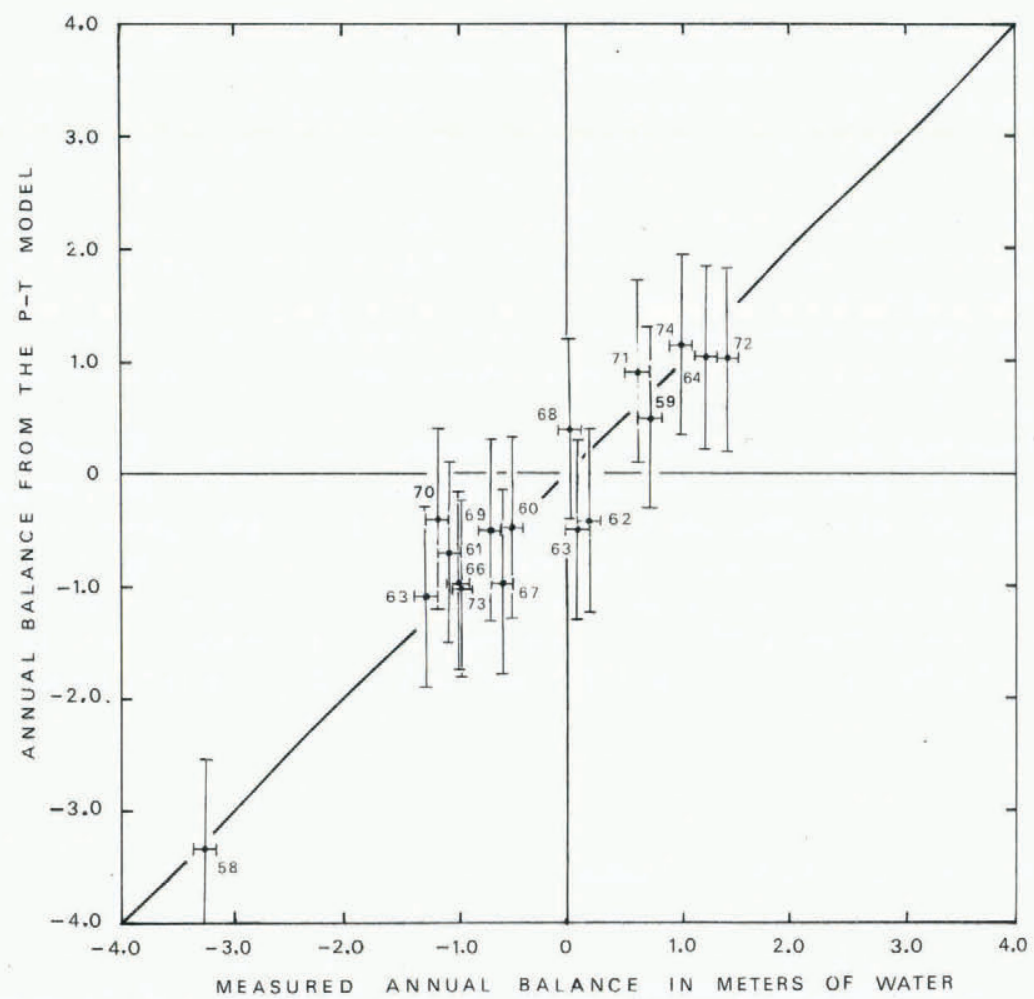

Fig. G. Measured (horizontal axis) versus predicted (vertical axis) annual balances for South Cascade Glacier for the 1958-74 period. The standard error limits for both methods are given for each determination of balance.

Several points of interest on these graphs can be elaborated:

I. The difference in trend between Thunder Creek and South Cascade Glacier can be explained by the difference in mean altitude (Thunder Creek glaciers, altitude $=2120$ $\mathrm{m}$, South Cascade, altitude $=\mathrm{I} 925 \mathrm{~m}$ ). The more negative balances on South Cascade Glacier are probably due more to the increase in ablation with decreasing altitude than to any differences in winter snow accumulation.

2. Short-lived growth occurred between 1947 and 1955. This understandably prompted speculation about a possible rejuvenation of Pacific Northwest glaciers (Hubley, I956; Harrison, 1956; LaChapelle, 1960). The reversal from the hundred-year period of drastic glacier shrinkage was first detected in 1946 by a slight thickening on the upper profile of Nisqually Glacier (Johnson, I960).

3. There is evidence that the retreat of Nisqually Glacier on Mount Rainier was halted for a few years around the turn of the century (Harrison, I954). The r8go advance of South Cascade Glacier disclosed by moraine-dating techniques (Meier, 1964; Miller, I967) appears to be confirmed by the maximum shown here at the end of the nineteenth century. An interruption of the marked, half-century recession of glaciers in the Alps in the I8gos is well known (Hoinkes, 1955). However, neither these results or nor other North Cascades studies (Miller, 1967) show a period of glacier advances in the early I 920 , such as occurred in the Alps and Norway.

4. The phenomenal loss of mass between 1900 and I945 has been observed for nearly all glaciers throughout the world (Ahlmann, 1948; Hoinkes, I955; Kasser, 1959; Schytt, 

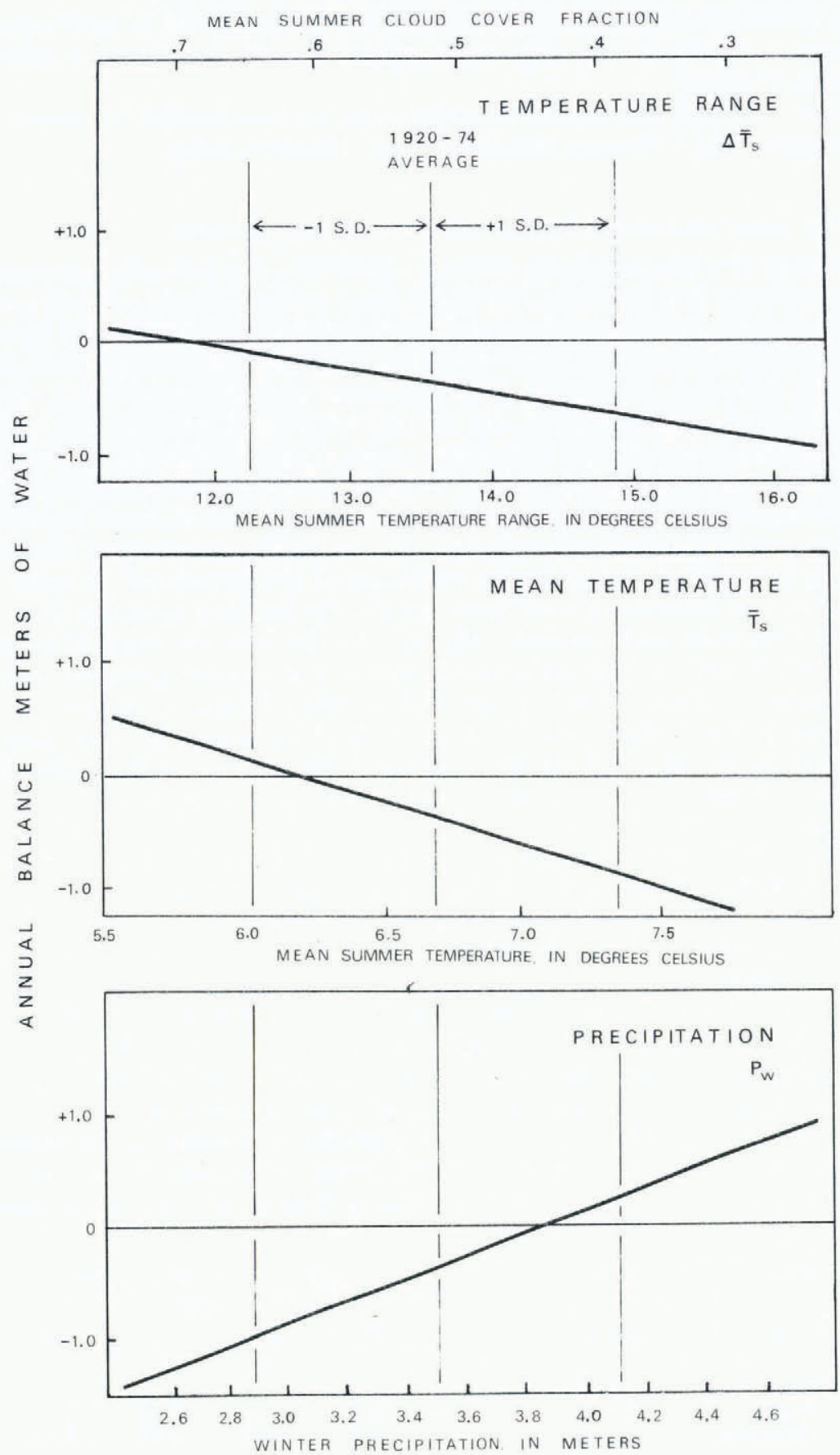

Fig. 7. Sensitivity of annual balance of the Thunder Creek glaciers to the three main climate variables that are related to glacier mass changes. Cloud-cover fraction (upper), related to the difference between mean summer maximum and minimum temperatures at Snoqualmie Falls, appears to be less important than mean summer temperatures (middle), adjusted to mean glacier altitude by an observed summer lapse rate of $0.4 \mathrm{deg} / \mathrm{I} 0 \mathrm{o} \mathrm{m}$, and winter precipitation (lower). The mean and standard deviation $(S D)$ of each variable are given so that direct comparisons of the significance of each variable can be made. 
I959; Grosval'd and Kotlyakov, I969). A corresponding rise in air temperature in the northern latitudes in the $1890-1940$ period is well established (Landsberg, I949; Mitchell, [ $\left.\left.{ }^{\mathrm{c}} \mathrm{I} 970\right]\right)$.

5. The four-year period of growth following 1932 has been verified by observations in both Washington and California (Matthes, I942; Harrison, I964).

\section{SENSITIVITy OF MASS BALANCE TO PREGIPITATION AND TEMPERATURE}

An advantage of a climate-glacier balance model that requires only elementary meteorological observations is that an assessment of past (and perhaps future) climatic conditions that affect man is possible. Both the precipitation and temperature variables used in the PT model are basic geophysical parameters upon which the survival of plant and animal species of the Earth depends. Moderate changes in either can cause economic hardships or even disastrous famines-particularly in regions that are on the borderline of consistently successful food production (Kukla, unpublished; Schneider, I976). Some of the serious food shortages in Europe recorded in medieval times were related to abnormal meteorological conditions (usually cold summers) which coincided with pronounced glacier advances (Ladurie, [ $\left.{ }^{\mathrm{c}} \mathrm{I}_{967}{ }^{6}\right]$ ).

By holding two of the three variables $\left(p_{\mathrm{w}}, \bar{T}_{\mathrm{s}}\right.$, and $\left.\Delta \mathcal{T}_{\mathrm{s}}\right)$ constant and allowing the third to fluctuate, it is possible to examine the sensitivity of glacier balance to each. In order to compare the relative influence of each conveniently, the standard deviation from the $1920-74$ mean was used to scale each variable (Fig. 7). In this way the slope of the line relating balance to precipitation and temperature is a means of determining relative sensitivity. The standard deviation is also useful to test the absolute effect of each factor that determines mass balance. If significant changes in balance (for example, a change in trend from negative to positive) occur within one standard deviation from the mean of each variable, this suggests that large-scale changes in glacier mass could easily take place with a barely perceptible climate change.

These results demonstrate that mean summer temperature in the North Cascades would need to have decreased by only $0.5 \mathrm{deg}$, or winter snow accumulation on these glaciers to have increased by only $10 \%$ of the $1920-74$ average $(350 \mathrm{~mm})$, to have made the balance of the Thunder Creek glaciers continuously positive during this period of extreme glacier recession. A trend toward both cooler and wetter weather would require even less change in these variables to cause glacier growth. It should be noted that continued glacier growth at these high altitudes does not necessarily mean indefinite growth at all altitudes. There would be an equilibrium position for each climatic situation, and a slightly renewed growth condition would soon be stabilized as the glaciers advanced to lower altitudes.

Another way of viewing the responsiveness of glaciers to climate is to examine the conditions when these glaciers are in three different modes of activity for similar time periods (Table IV). Based on the average of each variable during these diverse periods of glacier

TABle IV. The climatic conditions DURing Periods OF EXPANSION, Shrinkage, AND STABILITY OF THE THUNDER CREEK GLACIERS

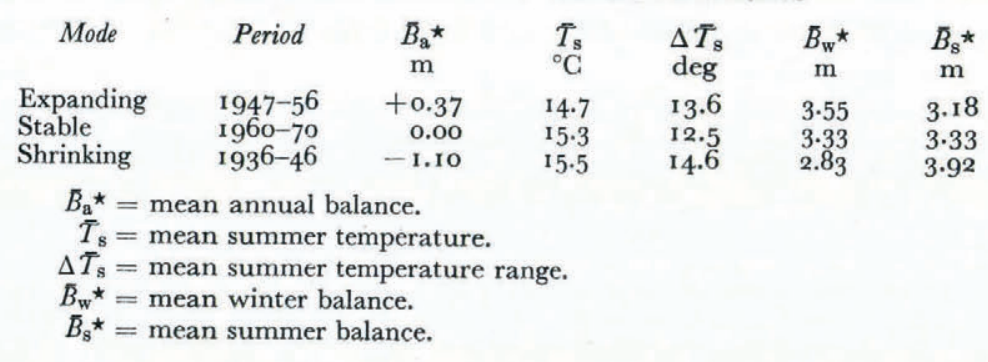


activity, it appears that extremely small departures from climate conditions prevalent during a period of stability are needed for rapid and large-scale changes in glacier size in this region. The transformation from an expanding to a shrinking glacier, and vice versa, requires a slightly greater change in climate.

\section{Conclusions}

Weather records from low-altitude stations can be used to estimate accumulation, ablation, and mass balance of glaciers in the North Cascades. These climate-glacier relationships (which it may be possible to determine in some other regions of the Earth by the same method) are useful in extending glacier balance records back in time and for relating the response of glaciers to climate more precisely. The next obvious step would be to use these climateglacier relationships to extend the climate record back several thousand years by using known glacier fluctuations determined by moraines and other datable evidence. This information would be of value to those interested in climate change and especially for such purposes as predicting the Earth's potential food production on the basis of both current and past climates.

MS. received 7 August 1978

\section{REFERENCES}

Agassiz, L. 1840. Étude sur les glaciers. Neuchatel, [the author]. [English translation: Studies on glaciers. Translated by A. V. Carozzi. New York and London, Hafner Publishing Co., 1967.]

Ahlmann, H. W. 1948. Glaciological research on the North Atlantic coasts. London, Royal Geographical Society. (R.G.S. Research Series, No. I.)

Ahlmann, H. W. 1953. Glacier variations and climatic fluctuations. New York, American Geographical Society. (Bowman Memorial Lectures, Series 3.)

Ambach, W. 1974. The influence of cloudiness on the net radiation balance of a snow surface with high albedo. Fournal of Glaciology, Vol. 13, No. 67, p. 73-84.

Ångström, A. 1925. On radiation and climate. Geografiska Annaler, Årg. 7, Ht. 1-2, p. 122-42.

Bodvarsson, G. 1955. On the flow of ice-sheets and glaciers. Fökull, Âr. 5, p. I-8.

Brooks, C. E. P. 1949. Climate through the ages. A study of the climatic factors and their variations. Revised edition. London, Ernest Benn.

Geiger, R. 1961. Das Klima der bodennahen Luftschicht. Vierte Auflage. Braunschweig, Friedrich Vieweg und Sohn. [English translation: The climate near the ground. Translated by Scripta Technica, Inc. Cambridge, Mass., Harvard University Press, 1965.]

Grosval'd, M. G., and Kotlyakov, V. M. 1969 . Present-day glaciers in the U.S.S.R. and some data on their mass balance. Fournal of Glaciology, Vol. 8, No. 52, p. 9-22.

Harrison, A. E. 1954. Fluctuations of the Nisqually Glacier, Mt Rainier, Washington, during the last two centuries. Union Géodésique et Géophysique Internationale. Association Internationale d'Hydrologie Scientifique. Assemblée générale de Rome 1954, Tom. 4, p. 506-10. (Publication No. 39 de l'Association Internationale d'Hydrologie Scientifique.)

Harrison, A. E. 1956. Fluctuations of the Nisqually Glacier, Mt Rainier, Washington, since 1750. Fournal of Glaciology, Vol. 2, No. 19, p. 675-76, 68o-83.

Harrison, A. E. 1964. Climate and glacier fluctuations. Transactions. American Geophysical Union, Vol. 45, No. 4, p. 6o8. [Abstract.]

Hoinkes, H. C. 1955. Measurements of ablation and heat balance on Alpine glaciers. Fournal of Glaciology, Vol. 2, No. 17, p. 497-501.

Hoinkes, H. C. 1968. Glacier variation and weather. Journal of Glaciology, Vol. 7, No. 49, p. 3-19.

Hoinkes, H. C., and others. 1968 . Glacier mass budget and mesoscale weather in the Austrian Alps 1964 to 1966 , [by] H. C. Hoinkes, F. Howorka, and F. Schneider. Union de Géodésie et Géophysique Internationale. Association Internationale d'Hydrologie Scientifique. Assemblée générale de Berne, 25 sept. -7 oct. 1967 . [Commission de Neiges et Glaces.] Rapports et discussions, p. 24-54. (Publication No. 79 de l'Association Internationale d'Hydrologie Scientifique.)

Holmgren, B. 1971. Climate and energy exchange on a sub-polar ice cap in summer. Part F. On the energy exchange of the snow surface at ice cap station. Meddelanden frän Uppsala Universitets Meteorologiska Institution, Nr. II2.

Hubley, R. C. 1956. Glaciers of the Washington Cascade and Olympic Mountains; their present activity and its relation to local climatic trends. Fournal of Glaciology, Vol. 2, No. 19, p. 669-74, 678-79.

Hubley, R. C. 1957. An analysis of surface energy exchange during the ablation season on Lemon Creek Glacier, Alaska. Transactions. American Geophysical Union, Vol. 38, No. I, p. 68-85. 
Johnson, A. 1960. Variation in surface elevation of the Nisqually Glacier, Mt Rainier, Washington. Bulletin of the International Association of Scientific Hydrology, No. r 9, p. 54-6o.

Kasser, P. I 959. Der Einfluss von Gletscherrückgang und Gletschervorstoss auf den Wasserhaushalt. Wasser-und Energiewirtschaft, Bd. 51, Nr. 6, p. 155-68.

Kukla, G. J. Unpublished. To feed the world; what to do with changing climate. [Paper presented at American Association for the Advancement of Science symposia, annual meeting, San Francisco, 24 February-1 March 1974.]

LaChapelle, E. R. 1959. Annual mass and energy exchange on the Blue Glacier. Fournal of Geophysical Research, Vol. 64, No. 4, p. $443-49$.

LaChapelle, E. R. 1960. Recent glacier variations in western Washington. Journal of Geophysical Research, Vol. 65 , No. 8, p. 2505. [Abstract.]

Ladurie, E. L. [ [ $\left.{ }^{1}{ }_{1} 67.\right]$ Histoire du climat depuis l'an mil. Paris, Flammarion. [English translation: Times of feast, times of famine; a history of climate since the year Iooo. Translated by B. Bray. Garden City, New York, Doubleday and Co., [ [ $\left.\left.{ }^{\mathrm{c}} \mathrm{I} 97 \mathrm{I}\right].\right]$

Landsberg, H. I949. Climatic trends in the series of temperature observations at New Haven, Connecticut. Geografiska Annaler, Årg. 31, Ht. 1-4, p. 125-32.

Manley, G. 1948. Glacier variations and climatic fluctuations in Britain. Union Géodésique et Géophysique Internationale. Association Internationale d'Hydrologie Scientifique. Assemblée générale d'Oslo, 19-28 août I948. Procèsverbaux des séances, Tom. 2, p. 304-05. [(Publication No. 30 de l'Association Internationale d'Hydrologie Scientifique.)]

Matthes, F. E. 1942. Glaciers. (In Meinzer, O. E., ed. Hydrology. New York, McGraw-Hill Book Co., p. 149-2 19. (Physics of the Earth, 9.))

Mayo, L. R., and others. 1972. A system to combine stratigraphic and annual mass-balance systems: a contribution to the International Hydrological Decade, by L. R. Mayo, M. F. Meier, and W. V. Tangborn. Journal of Glaciology, Vol. i 1, No. 61, p. 3-14.

Meier, M. F. I 964 . The recent history of advance-retreat and net budget of South Cascade Glacier. Transactions. American Geophysical Union, Vol. 45, No. 4, p. 6o8. [Abstract.]

Meier, M. F. 1965. Glaciers and climate. (In Wright, H. E., jr, and Frey, D. G., ed. The Quaternary of the United States. Princeton, N.J., Princeton University Press, p. 795-805.)

Meier, M. F. 1966. Some glaciological interpretations of remapping programs on South Cascade, Nisqually, and Klawatti Glaciers, Washington. Canadian fournal of Earth Sciences, Vol. 3, No. 6, p. 81 I-1 8.

Meier, M. F. 1969. Glaciers and water supply. Fournal, American Water Works Association, Vol. 61, No. 1, p. 8-1 2.

Meier, M. F., and Post, A. S. 1962. Recent variations in mass net budgets of glaciers in western North America. Union Géodésique et Géophysique Internationale. Association Internationale d'Hydrologie Scientifique. Commission des Neiges et des Glaces. Colloque d'Obergurgl Io-9-18-9 1962, p. 63-77. (Publication No. 58 de l'Association Internationale d'Hydrologie Scientifique.)

Meier, M. F., and Tangborn, W. V. 1965. Net budget and flow of South Cascade Glacier, Washington. Journal of Glaciology, Vol. 5, No. 4i, p. 547-66.

Meier, M. F., and others. $197 \mathrm{I}$. Ice and water balances at selected glaciers in the United States. Combined ice and water balances of Gulkana and Wolverine Glaciers, Alaska, and South Cascade Glacier, Washington, 1965 and 1966 hydrologic years, by M. F. Meier, W. V. Tangborn, L. R. Mayo, and A. [S.] Post. U.S. Geological Survey. Professional Paper 715-A.

Miller, C. D. 1967 . Chronology of neoglacial moraines in the Dome Peak area, North Cascade Range, Washington. Arctic and Alpine Research, Vol. I, No. 1, p. 49-65.

Mitchell, J. M., jr. [ $\left.{ }^{\mathrm{C}} \mathrm{I} 970.\right]$ A preliminary evaluation of atmospheric pollution as a cause of the global temperature fluctuation of the past century. (In Singer, S. F., ed. Global effects of environmental pollution. A symposium organized by the American Association for the Advancement of Science held in Dallas, Texas, December 1968. Dordrecht, D. Reidel Publishing Co., p. 139-55.)

Müller, F., and Keeler, C. M. 1969. Errors in short-term ablation measurements on melting ice surfaces. Fournal of Glaciology, Vol. 8, No. 52, p. 91-105.

Nye, J. F. 1960. The response of glaciers and ice-sheets to seasonal and climatic changes. Proceedings of the Royal Society of London, Ser. A, Vol. 256, No. 1287, p. 559-84.

Nye, J. F. 1963. The response of a glacier to changes in the rate of nourishment and wastage. Proceedings of the Royal Society of London, Ser. A, Vol. 275, No. 1360, p. 87-112.

Paterson, W. S. B. 1969. The physics of glaciers. Oxford, etc., Pergamon Press. (The Commonwealth and International Library. Geophysics Division.)

Post, A. S., and others. 1971. Glaciers in the United States. Inventory of glaciers in the North Cascades, Washington, by A. [S.] Post, D. Richardson, W. V. Tangborn, and F. L. Rosselot. U.S. Geological Survey. Professional Paper 705-A.

Rasmussen, L. A., and Tangborn, W. V. 1976. Hydrology of the North Cascades region, Washington. 1. Runoff, precipitation, and storage characteristics. Water Resources Research, Vol. 12, No. 2, p. 187-202.

Schneider, S. H., and Mesirow, L. E. I976. The Genesis strategy. New York, Plenum Press.

Schytt, V. I 959. The glaciers of the Kebnekajse-massif. Geografiska Annaler, Vol. 41, No. 4, p. 2 I 3-27.

Tangborn, W. V. 1968 . Mass balances of some North Cascade glaciers as determined by hydrologic parameters, 1920-1965. Union de Géodésie et Géophysique Internationale. Association Internationale d'Hydrologie Scientifique. Assemblée générale de Berne, 25 sept.-7 oct. 1967. [Commission de Neiges et Glaces.] Rapports et discussions, p. 267-74. (Publication No. 79 de l'Association Internationale d'Hydrologie Scientifique.)

Tangborn, W. V., and Rasmussen, L. A. 1976. Hydrology of the North Cascades region, Washington. 2. A proposed hydrometeorological streamflow prediction method. Water Resources Research, Vol. 12, No. 2, p. $203^{-16}$. 
Tangborn, W. V., and others. [1975.] A comparison of glacier mass balance by glaciological, hydrological, and mapping methods, South Cascade Glacier, Washington, [by] W. V. Tangborn, R. M. Krimmel, and M. F. Meier. [Union Géodésique et Géophysique Internationale. Association Internationale des Sciences Hydrologiques. Commission des Neiges et Glaces.] Symposium. Neiges et glaces. Actes du colloque de Moscow, août 1971, p. 185-96. (IAHS-AISH Publication No. 104.)

Tangborn, W. V., and others. 1977. Ice and water balances at selected glaciers in the United States. Combined ice and water balances of Maclure Glacier, California, South Cascade Glacier, Washington, and Wolverine and Gulkana Glaciers, Alaska, 1967 hydrologic year, by W. V. Tangborn, L. R. Mayo, D. R. Scully, and R. M. Krimmel. U.S. Geological Survey. Professional Paper 715-B.

Troitskiy, L. S., and others. 1966. Oledeneniye Urala [The glacierization of the Urals]. [By] L. S. Troitskiy [and 6 others]. Rezul'taty Issledovaniy po Programme Mezhdunarodnogo Geofizicheskogo Goda. IX Razdel Programmy MGG, No. 16.

UNESCO/IASH. 1970. Combined heat, ice, and water balances at selected glacier basins: a guide for the compilation and assemblage of data for glacier mass balance measurements. Paris, UNESCO/IASH. (Technical Papers in Hydrology, 5.)

U.S. Army. Corps of Engineers. 1956. Summary report of the snow investigations. Snow hydrology. Portland, Oregon, U.S. Army. Corps of Engineers. North Pacific Division.

Wallén, C. C. 1948. Glacial-meteorological investigations on the Kårsa glacier in Swedish Lappland 1942-1948. Geografiska Annaler, Årg. 30, Ht. 3-4, p. 451-672. 